\title{
FINAL OFFER ARBITRATION: AN INNOVATIVE INSTITUTION IN THE ADR MARKET
}

\author{
UDC 347.918
}

\author{
Aleksandar Mojašević \\ Faculty of Law, University of Niš, Republic of Serbia
}

\begin{abstract}
In this paper, we present a new form of arbitration called the Final Offer Arbitration (FOA), which is insufficiently known to the domestic public. It is a form of arbitration that was initially used in American practice for solving labor disputes in the field of sport and the public sector. Since its inception, it has attracted the attention of scholars and researchers who have started to examine its efficiency in relation to the traditional form of arbitration. In this context, we first present current theoretical and empirical knowledge about the advantages of the traditional arbitration over litigation. Then, we focus on the comparative advantages of the final offer arbitration in relation to the traditional arbitration, primarily in terms of its efficiency. An issue of particular interest is which of these two models of arbitration, the traditional or the innovative one, provides stronger incentives to the disputing parties to enter the process of negotiation and final settlement.
\end{abstract}

Key words: traditional arbitration, Final Offer Arbitration, efficiency, negotiations, settlement.

\section{INTRODUCTION}

The Final Offer Arbitration (FOA) is an innovative model of arbitration which originated in America and is insufficiently known in Serbia. In recent decades, a very developed market of alternative dispute resolution methods (ADR) in the United States has fostered numerous institutional innovations, primarily aimed at meeting the needs of economic entities for a faster, cheaper and more convenient way of resolving disputes. Thus, for example, it has fostered the development of the Private Judging, the Mini-Trial, the MedArb, the Summary Jury Trial, the Fact Finding, and others. In addition, this market has "engendered" the FOA since the traditional arbitration (TA), which has already proved its efficiency as compared to litigation, exhibited certain flaws.

Starting from the well-known advantages of arbitration over litigation, in this paper we want to elaborate on the development of this legal institute and its institutional

Received December $14^{\text {th }}, 2016 /$ Accepted December $24^{\text {th }}, 2016$

Corresponding author: Aleksandar Mojašević, LL.D.

Faculty of Law, University of Niš, Trg Kralja Aleksandra 11, 18000 Niš, Republic of Serbia

E-mail: mojasevic@prafak.ni.ac.rs 
transformation into an innovative form: the Final Offer Arbitration (FOA). The need to provide a comprehensive analysis of this innovative legal institute is further justified by the fact that our legal scholars and practitioners, as well as the general public, are insufficiently aware of the FOA advantages.

\section{THE AdVANTAGES OF ARBITRATION OVER LitIGATION}

Traditional arbitration (TA) has numerous advantages over litigation as a regular method of dispute resolution. First of all, the TA is based on the principle of voluntariness, when the parties select an arbitrator (or arbitrators), either in advance (ex ante) or after the dispute has arisen (ex post), to assist them in the dispute resolution, whereby the arbitrator's decision should_substitute for the judicial decision. However, there are situations when arbitration is compulsory; for example, in the American legal system, it is required for the settlement of labor disputes in the public sector. Also, in our legal system, ${ }^{1}$ the parties (employer, union or employee representative) are obliged to peacefully settle a collective dispute $^{2}$ concerning a subject matter of public interest.

In theory (Benson, 2000: 162), it is pointed out that the arbitrator, being an expert in a particular field (unlike a judge), makes decisions on the basis of a smaller amount of information received from the parties, which implies that the arbitration proceeding entails lower transaction (information) costs as compared to litigation. The arbitrator's expertise is a reason why Benson believes that there is a lower probability of making mistakes in rendering an arbitral decision as compared to litigation. In this connection, Mnookin (Mnookin, 1998) points to the greater predictability of arbitral decision in relation to the judicial one. Such predictable and reliable decision generates lower transaction costs of the arbitration proceeding. In addition, the predictability of the arbitral decision increases the likelihood of concluding an agreement between the parties before the arbitration proceeding has already started.

Relevant literature (Cole, Blankey, 2005: 319) points out that the arbitration proceeding is faster (and cheaper) as compared to court proceedings. This advantage of arbitration stems from the fact that the arbitral decision, unlike a judicial one, in principle, cannot be appealed, i.e. that arbitration is a single-stage proceeding. Also, the delivery system is more efficient in arbitration than in litigation, for which reason the former gains a competitive advantage over the latter.

Some theorists (Ashenfelter, 1987: 342-343) underscore that the arbitration creates incentives for the competitive behavior of arbitrators, which ultimately results in the adoption of impartial and professional decisions. Namely, given that the arbitrators are selected by the disputing parties, arbitrators are encouraged to develop expertise and bring more qualified decisions in relation to those rendered in the past. In other words, the arbitrators are incentivized to bring professional and impartial decisions in order to increase the likelihood of future re-appointment. This fact is one of the reasons for favoring arbitration over litigation, where there is no competition between the judges to make decisions (on the basis of their expert knowledge) that can improve the previous ones. ${ }^{3}$

\footnotetext{
${ }^{1}$ See: Art. 18 of the Act on the Peaceful Settlement of Labor Disputes, Official Gazette of the RS, 125/04, 104/09.

${ }^{2}$ It is a collective dispute concerning: conclusion, amending and supplementing, or application of a collective agreement; exercising the right to join a trade union; and exercising the right to strike. See: Art. 2. par. 1 items 1, 3 and 4 of the Act on the Peaceful Settlement of Labor Disputes.

${ }^{3}$ The arbitrators who take extreme positions in relation to their colleagues take a risk that one or both parties will not choose them in the future. Therefore, a successful arbitrator's strategy is the one that does not stand out too much from
} 
Legal theorists (Knežević, Pavić, 2009: 20) emphasize some other advantages of arbitration over litigation. First of all, the confidentiality of arbitration has been reflected in the private character of the proceeding, which indicates to the similarity with the mediation process. Another common feature of arbitration and mediation is that the facts stated in these proceedings may not be used as evidence in a regular judicial proceeding. Also, unlike litigation, arbitration is a flexible procedure for resolving disputes. Yet, if the parties have not determined the procedural framework of arbitration, it will be done by the arbitrator (or arbitrators).

Then, there are authors (Charny, 1990) who favor arbitration over litigation because, among other things, the enforcement of arbitral decisions is guaranteed not only by formal but also by informal sanctions (for example, the reputation of companies), which is particularly evident in the long-term business relationships. According to Charny, arbitration is based on the private incentives system that is significantly more efficient than the public incentives system, which litigation rests on.

Finally, there is a lower level of antagonistic relationship between the parties in arbitration as compared to litigation. This feature makes arbitration a convenient method of resolving disputes, especially between the parties that are already involved in long-term business relationship and want to maintain and further develop their relations (Benson, 2000: 164).

Table 1 Comparative advantages of arbitration over litigation

\begin{tabular}{|c|c|c|}
\hline & Arbitration & Litigation \\
\hline Initiation of the proceeding & $\begin{array}{l}\text { Consensual (ex ante, ex post) } \\
\text { or forced by law }\end{array}$ & $\begin{array}{l}\text { Legal claim is filed by an injured } \\
\text { party (the plaintiff) }\end{array}$ \\
\hline $\begin{array}{l}\text { General features of } \\
\text { the proceeding }\end{array}$ & $\begin{array}{l}\text { - Private (confidential) } \\
\text { - Informal (flexible) } \\
\text { - Economical (cost-effective, } \\
\text { time-effective) }\end{array}$ & $\begin{array}{l}\text { - Public } \\
\text { - Formal (strict rules) } \\
\text { - Uneconomical } \\
\text { (expensive, lengthy) }\end{array}$ \\
\hline Length of the proceeding & $\begin{array}{l}\text { Shorter procedure: } \\
\text { - informal single-stage proceeding } \\
\text { - time limit } \\
\text { - efficient delivery }\end{array}$ & $\begin{array}{l}\text { Longer procedure: } \\
\text { - formal multistage proceeding } \\
\text { - lack of a time limit } \\
\text { - inefficient delivery }\end{array}$ \\
\hline Costs of the proceeding & $\begin{array}{l}\text { Lower costs: } \\
\text { - smaller amount of information } \\
\text { required for the decision making } \\
\text { - lower opportunity costs }\end{array}$ & $\begin{array}{l}\text { Higher costs: } \\
\text { - the costs of obtaining and } \\
\text { presenting the evidence } \\
\text { - higher opportunity costs }\end{array}$ \\
\hline Quality of decision & $\begin{array}{l}\text { - the decision is brought } \\
\text { by an expert } \\
\text { - higher degree of predictability } \\
\text { - enforcement of decisions } \\
\text { guaranteed by formal and informal } \\
\text { sanctions }\end{array}$ & $\begin{array}{l}\text { - the decision is brought } \\
\text { by a judge } \\
\text { - lower degree of predictability } \\
\text { - enforcement of decisions } \\
\text { guaranteed by formal sanctions }\end{array}$ \\
\hline $\begin{array}{l}\text { Selection of } \\
\text { decision-makers }\end{array}$ & $\begin{array}{l}\text { Selection of an arbitrator by the } \\
\text { parties: } \\
\text { - competitive behavior of arbitrators }\end{array}$ & $\begin{array}{l}\text { Selection of judges by the } \\
\text { competent authorities: } \\
\text { - uncompetitive behavior of judges }\end{array}$ \\
\hline $\begin{array}{l}\text { Relationship between } \\
\text { the parties }\end{array}$ & $\begin{array}{l}\text { - lower level of antagonism } \\
\text { - higher degree of parties' } \\
\text { satisfaction }\end{array}$ & $\begin{array}{l}\text { - intensified hostility } \\
\text { - lower level of parties' } \\
\text { satisfaction }\end{array}$ \\
\hline
\end{tabular}

the strategy of other arbitrators. In this way, the arbitrators' decisions, as well as their mistakes in decision making, become predictable, for which reason arbitration gains a competitive advantage over litigation. 
Inter alia, due to these prominent characteristics, arbitration has gained wider use in the business practice, especially in the international environment, and has increasingly prevailed over litigation. Thus, we can now talk about creating a different system of (private) law in which arbitration has a special role as the main method of dispute resolution (Wooldridge, 1970: 101).

Yet, despite the fact that arbitration (particularly international arbitration) has been perceived by business entities as a cheaper, faster, more flexible and more confidential method of dispute resolution as compared to litigation, some theoreticians (Lookofsky, Hertz 2004: 756) indicate that this private method generates significant costs (for instance, the arbitrators' fees), that it is not always carried out rapidly, and that the arbitral decisions are not completely isolated from the public eye, which calls into question the principle of absolute confidentiality of the arbitration proceeding.

Therefore, the question is whether and how the other forms of arbitration can overcome certain disadvantages of the traditional arbitration. Further on, from the standpoint of economic analysis of law, we will focus on the innovative model of arbitration: the Final Offer Arbitration (FOA).

\section{FinAl OFFER ARbitRATION VS. TRADITIONAL ARBITRATION}

In the traditional model of arbitration, the arbitrator may encounter a peculiar situation where he/she is unable to make a decision which would satisfy the needs of both disputing parties. This occurs when the parties take the extreme positions, and none of them wants to give in. It happened in practice that the arbitrator had to mechanically resort to "splitting the difference" between the extreme demands (i.e. he/she had to mechanically search for a compromise), the ultimate result of which was dissatisfaction of the disputing parties.

For this reason, among other things, the ADR market in America gave birth to an institutional innovation embodied in the Final Offer Arbitration. This model of arbitration was initially used for resolving disputes over the salary of athletes (baseball players), as well as for resolving labor disputes in the public sector (Nolan-Haley, 1991: 130-131).

Within this innovative model of arbitration, the disputing parties give a "final offer" to the arbitrator, from which he/she can choose only one. The benefits of this method are two-fold. First of all, it facilitates the process of rendering the arbitral award as it actually relieves the arbitrator of personal responsibility of making a decision that would be acceptable to both disputing parties. Second, each party is encouraged to make a reasonable offer, in order to reduce the risk of having the other party's offer accepted and increase the likelihood of having its own offer accepted. For example, in an employer-employee dispute on the amount of wages, an unreasonable offer could be the employees' demand for a disproportionately high increase in wages. Considering that unreasonable offers are quite common in the traditional model of arbitration, the innovative model of arbitration (FOA) proves to be more than efficient.

In this regard, the following question arises: why is there a higher frequency of unreasonable offers in the traditional arbitration as compared to the FOA? The answer to this question lies in the incentives which the parties (as rational persons) are exposed to within these two models. Namely, in the traditional model of arbitration, the parties encounter weaker incentives to negotiate and conclude agreement. This is due to the fact 
that the presence of the arbitrator in this model creates the parties' expectations that he/she should settle their dispute. In economic theory, this phenomenon of reducing personal responsibility and personal engagement is referred to as a moral hazard. Anticipating that a third party (the arbitrator) will resolve their dispute anyway, the parties start acting strategically, which means that they take extreme positions by making unreasonably high offers (demands). Therefore, the arbitrator may be in an extremely delicate situation, in which case he/she usually resorts to "splitting the difference", i.e. mechanically seeking for a compromise. Because of this flaw of the traditional arbitration, it would be preferable if the parties tried to solve the dispute without the presence of a third person, thus avoiding this adverse outcome of their strategic behavior. But, in the TA model, it is highly unlikely to happen.

On the other hand, the FOA creates different incentives prompting the parties' behavior towards negotiation. Specifically, within this model, knowing that the arbitrator will have to choose one of the offers, each party assumes that the other will make a reasonable offer, which increases the likelihood of having such an offer accepted by the arbitrator. Considering such an outcome of the arbitration process (i.e. accepting one of the reasonable offers), the parties will be induced to negotiate and attempt to resolve the dispute before the arbitration proceeding actually starts. Thus, the FOA increases the likelihood of concluding an agreement by direct negotiations between the parties.

Therefore, in the traditional model of arbitration, the parties are the parties tend to take extreme positions and the arbitrators have the ultimate responsibility for the outcome of the dispute. On the other hand, in the innovative FOA model, the parties are stimulated to resolve the dispute by direct negotiations before the initiation of the arbitration process. However, in theory, there is some disagreement about the advantages of the FOA over the TA, which will be discussed further on in this paper.

\section{EFFICIENCY OF DIFFERENT MODELS OF ARBITRATION: DIFFERENT VIEWS}

There are authors, such as Stevens (Stevens, 1966: 45-47), who favor the FOA over the TA because the former creates stronger incentives for settling a dispute. Otherwise, this author distinguishes two types of this innovative model of arbitration, and a key difference is that the second type includes a fair hearing by the arbitrator. Also, the second type has a different composition, since it is composed of the parties' representatives and the neutral members who who are in the minority (the so-called tripartite arbitration). Since the neutral members can control the outcome of the arbitration, they have a special role. This control stems from their right to vote for one or other party, which may affect the parties to bring their offers closer together and come to a mutually acceptable solution. It is obvious that these neutral members actually act as mediators; so, this form of the final offer arbitration has the characteristics of arbitration and mediation.

On the other hand, Crawford (Crawford, 1979) developed a model of arbitration and negotiation which includes a significant innovation: the arbitrator's preferences in terms of a final solution of the dispute. Starting from the assumption that the parties know the arbitrator's preferences in terms of the final solution, they will not independently conclude an agreement that would be much different from the previous one. Consequently, the result of the game would be the same, regardless of whether it comes to the (traditional) arbitration or direct negotiation. 
Yet, when it comes to the FOA, given the possibility of choice, the arbitrator's behavior is changing, because he/she can always choose the offer that is most similar to the preferring decision. On the other hand, knowing the arbitrator's preferences, the parties are induced to give offers that are consistent with these preferences, thus increasing the likelihood of having them accepted. It follows that the final solution will be the result of the arbitrator's preferences rather than the parties' preferences. If that is so, the parties could settle before the initiation of the arbitration proceeding.

Thus, according to Crawford, the traditional as well as the innovative model of arbitration creates identical incentives towards negotiating, under the previously mentioned basic assumption. In other words, the parties are encouraged to conclude an agreement before the initiation of the proceeding in the both models. For this reason, and given that the FOA would impose (unnecessary) costs ${ }^{4}$ on the parties, the author concludes that this innovative model would not be used at all. It follows that the FOA has no advantage over traditional arbitration, which is an opinion that is contrary to the Stevens' one.

In a further criticism of the innovative model of arbitration, Crawford highlights that it can create a so-called prisoner's dilemma, i.e. an uncooperative game solution (Crawford, 1979: 152). In other words, guided by their self-interest, the parties can make offers that would lead to a suboptimal solution in relation to the solution that would be achieved by their cooperation and mutual communication. Relying on this criticism, among other things, Crawford proposed the thesis that the innovative model of arbitration does not increase the likelihood of concluding the agreement.

Furthermore, this author has rightly pointed out (Crawford, 1979: 143-150, 152) that the FOA generates costs, just like the TA. Namely, if negotiations encouraged by this form of arbitration fail, the parties will consume unnecessary costs. Also, in the event of a dispute over a large number of issues, Crawford has well noted that the parties could propose in their final offers a large number of inefficient solutions. Considering that the arbitrator is bound to select one of the offers, the inefficient outcome would be inevitable. This result could be avoided if the parties resorted to the traditional arbitration, where the arbitrator is not bound by any of the parties' offers but has a complete discretion in decision making. Finally, in addition to the traditional arbitration, Crawford supports the introduction of the multiple final offer arbitration, that is, arbitration in which the parties have an opportunity to send a large number of offers.

Crawford's model has also been subject to criticism. Some authors (Ashenfelter, Bloom, 1984: 112) consider that, in his model, Crawford ignores the impact of the costs of arbitration on the parties' behavior. Namely, in order to avoid the arbitration costs, the parties may simply agree and achieve the same outcome as in the arbitrator's decision. It follows that in this model a key determinant of the parties' behavior is arbitration rather than negotiation. Hence, these authors call into question Crawford's conclusion and state that the presence of arbitration in the model is very important because of the incentives that it creates.

Another critical remark on Crawford's model is aimed at his basic assumption that the parties know the arbitrator's preferences. This is a rather unrealistic assumption. There are authors (Farber, Katz, 1979: 55-63) who start from a more realistic assumption that the parties are not sure what the arbitrator's preferences are. Due to the lack of knowledge, the parties

${ }^{4}$ The costs are unnecessary because the same outcome can be achieved before the arbitration proceeding has been initiated. 
develop certain expectations about what the arbitrator's decision will be on the basis of selfpreferring risk. Therefore, if the parties have divergent expectations of what the arbitrator's decision will be, the possibility of reaching an agreement in direct negotiations will decrease. Also, if one party is inclined to risk, the likelihood of going to arbitration will increase. Accordingly, these variables (the parties' divergent expectations about the outcome of the arbitration and their propensity or aversion to risk) have an affect on the choice between arbitration (the traditional and the final offer arbitration) and negotiation.

One of the critical remarks aimed at the FOA is that it allows for favoring one party in the dispute. In this regard, in one study (Ashenfelter, Bloom, 1983: 534-539), the researchers tested the hypothesis that the arbitrators, for the reasons of bias, accept to a greater extent the offers of labour unions in relation to the offers of employers. The research showed that the arbitrators accepted the labour unions' offers to a greater extent because these offers were considerably more conservative in relation to the central tendency of the preferred arbitrators' decisions. The conservatism of these offers derives from the conservative views of unions in terms of what the arbitrators would accept, or from a greater fear of taking a risk that their offers would be rejected by the arbitrators. So, the arbitrators did not treat employers' offers differently from the the unions' ones; they simply accepted the labour unions' offers to a greater extent considering that the frequency of the unions' conservative offers was considerably higher than the frequency of the employers' "generous" offers. It follows that the credibility of this arbitration model cannot be called into question; similarly, the lightly addressed criticism that the FOA allows for favoring one party has no justification.

Furthermore, in literature (Benson, 2000: 180), there is an argument that the FOA is riskier for the parties than the TA. Namely, if the parties do not reach an agreement in the negotiations, they will bear significant costs; therefore, the FOA would be much risker for them as it provides incentives to the parties to negotiate. In other words, the parties would be at risk of failing to resolve the dispute, and would thus bear unnecessary negotiation costs within this innovative model. Also, in the FOA, the expected arbitration decision is expressed by the probability weighted as an average of two points (the two offers), while in the TA, it is expressed by the probability weighted as an average of distribution of a large number of potential decisions. In that sense, the FOA is riskier for the parties than the TA.

However, some authors (Farber, Bazerman, 1989: 99-120) did not accept this stance and proved in their research that the FOA actually reduces the risk for the parties, but also that there is a larger space for concluding agreement (i.e. more alternatives) in case of the TA. Accordingly, if the larger space meant a greater likelihood of concluding a settlement agreement, negotiations would be more frequent in the case of the TA. Such interpretation of the research results would lead to the conclusion that is diametrically opposite to the prominent one that the FOA provides stronger incentives for negotiations. However, this kind of interpretation was justifiably criticized; Benson noted that that larger space for the conclusion of agreement does not necessarily increase the probability of concluding it (Benson, 2000: 180-181). The argument is based on the existence of transaction costs of negotiations as well as the uncertainty about the outcome of negotiations, in a situation where there is a larger space (more alternatives) for making an agreement. This calls into question the very interpretation of research results that the TA provides stronger incentives for negotiations and concluding agreements. Therefore, the more credible argument seems to be the one that the FOA more frequently encourages the conclusion of agreements. 
This thesis may be confirmed by the findings in the aforementioned study (Farber, Bazerman, 1989), which also demonstrated that the latest offers addressed to the arbitrator (based on the expected utility maximization) are closer to each other in the case of the FOA than in the case of the TA. If the offers are closer to each other, it is more likely that the parties will conclude an agreement and reduce the costs of arbitration.

However, relatively recent research (Burgess, Marburger, 1993: 548-559) suggests the opposite finding: that the FOA actually generates increased costs, which which ultimately makes it a less appealing option. More specifically, the research shows that the arbitrators' decisions significantly deviate from the (comparatively studied) agreements concluded in the disputes over salary of baseball players in America. The fact that the arbitrators' decisions differ from the parties' agreements concluded in direct negotiations indicates their "low quality" and reduces the attractiveness of the FOA.

All in all, it is hard to make a general conclusion on the FOA superiority over the TA because studies indicate otherwise, at least when it comes to the disputes in some areas (such as sports). In addition, another research (Farber, Bazerman, 1986: 819-844) suggests that, systematically speaking, the arbitrator's behavior (in terms of decision-making) does not differ within the two models of arbitration (traditional or innovative). This finding, as well as a number of other studies (Farber, 1981; Bloom, 1986), disproves the thesis that the arbitrator mechanically pursues a compromise between the parties within the TA framework. Broadly speaking, it suggests that the distinction between the TA and the FOA may not be as substantial as it is assumed, at least when it comes to rendering arbitral decisions.

But, can this conclusion equally apply when it comes to the impact of the TA on the frequency of concluding settlement agreements? This issue will be addressed further on, with specific reference to the empirical research on this topic.

Table 2 Summary advantages and disadvantages of different arbitration models

\begin{tabular}{lcccccc}
\hline & $\begin{array}{c}\text { Frequency } \\
\text { of } \\
\text { settlements }\end{array}$ & $\begin{array}{c}\text { Parties' } \\
\text { Behavior }\end{array}$ & $\begin{array}{c}\text { Arbitrator's } \\
\text { Behavior }\end{array}$ & $\begin{array}{c}\text { The costs of } \\
\text { proceeding }\end{array}$ & $\begin{array}{c}\text { Dispute over a } \\
\text { large number of } \\
\text { issues }\end{array}$ & $\begin{array}{c}\text { Risk for } \\
\text { parties }\end{array}$ \\
\hline $\begin{array}{l}\text { Traditional } \\
\text { arbitration }\end{array}$ & $\begin{array}{c}\text { Lower } \\
\text { (majority } \\
\text { opinion) }\end{array}$ & $\begin{array}{c}\text { Taking } \\
\text { extreme } \\
\text { positions }\end{array}$ & $\begin{array}{c}\text { Mechanical } \\
\text { search for } \\
\text { compromise }\end{array}$ & $\begin{array}{c}\text { Higher } \\
\text { (in theory) }\end{array}$ & Advantage & Lower \\
$\begin{array}{l}\text { Final offer } \\
\text { arbitration }\end{array}$ & $\begin{array}{c}\text { Higher } \\
\text { (minority } \\
\text { opinion) }\end{array}$ & $\begin{array}{c}\text { Possibility of } \\
\text { the prisoners' } \\
\text { dilemma }\end{array}$ & $\begin{array}{c}\text { Partiality } \\
\text { (in theory) }\end{array}$ & $\begin{array}{c}\text { Lower } \\
\text { (in theory) } \\
\text { Higher } \\
\text { (in research) }\end{array}$ & Disadvantage & Higher \\
\hline
\end{tabular}

\section{DiFFERENT Models of ARBITRATION AND FREQUENCY OF SETTLEMENTS}

It is said that the TA reduces the incentives to negotiate and conclude an agreement. This incentives reduction is known as "the chilling effect" because the traditional model of arbitration "cools down " the incentives of the parties to negotiate. Researchers have questioned why this "chilling" effect occurs and some of the answers to this question are presented below. 
One of the most representative studies (Currie, 1989) indicates that the parties, in the presence of a third party (the arbitrator), demonstrate a high degree of confidence in the resolution of the dispute as compared to the direct negotiations. The parties prefer entrusting the resolution of the dispute to the arbitrator than attempting independently to find a solution, because he/she provides safety to them. The author of this research coined the term "narcotic effect" for this phenomenon. Namely, the negotiators who hired an arbitrator in the former stage of negotiations demonstrated at least $10 \%$ more interest in using arbitration in the current stage of negotiations as compared to those negotiators who have not previously met the arbitrator. This suggests that the parties who have already met the arbitrator apparently demonstrate the need to use his/her services in the future disputes (the narcotic effect). The parties simply realize that the benefits of arbitration are greater than they previously believed; thus, if the costs of negotiations are substantial, they are more likely to opt for for arbitration.

Despite the fact that the existence of this effect has been proven, there was no explanation for its existence. The aforementioned study showed that the total number of arbitrations in the previous years ${ }^{5}$ had a more negative than a positive impact on the likelihood that the negotiators will use arbitration. Also, the research demonstrated that the standard factors (such as: risk aversion; the parties' divergent expectations regarding the arbitral decision; different degree of uncertainty in connection with the arbitration decision, etc.) cannot explain this effect since these factors have an insignificant impact on the probability of using arbitration.

However, despite the lack of established factors, the existence of this effect has been confirmed, which is important for explaining the lower level of opting for negotiations as compared to arbitration. In this regard, one of the (alternative) explanations (Bloom, 1981) is that arbitration is a less expensive option. This means that the parties perceive the (mandatory) arbitration as less costly in comparison to (direct) negotiations, for the purpose of securing the fulfillment of contract terms which have given rise to the dispute. This explanation looks at the relation between arbitration and negotiations from a purely economic perspective; thus, we may agree with this explanation if it is trustworthy.

Finally, we underscore the aforementioned research results (Farber, Bazerman, 1989) which examined the frequency of negotiations assuming the existence of two models of arbitration (the traditional and the innovative one). This research has shown that the FOA increases the likelihood of negotiating and concluding an agreement because it induces the parties to bring their offers closer together. The result of this research (as well as intuitive thinking) indicates that the FOA provides incentives to the parties to directly negotiate and conclude a settlement agreement.

\section{INSTEAD OF CONCLUSION}

Therefore, can we consider the Final Offer Arbitration (FOA) as the preferred institutional arrangement, provided that it stimulates the parties to negotiate? The economic criterion is the only reliable criterion for assessing the preferability of one or another institutional arrangement. In other words, relying on the assessment of the level of transaction costs of

\footnotetext{
${ }^{5}$ It is a period of 35 years in which the effects of the mandatory arbitration had been studied, including the participation of American scholars.
} 
negotiations and arbitration, we can give a critical opinion on the advantages/disadvantages of one or the other arrangement on the merits of each particular case. When it comes to arbitration, the transaction costs greatly depend on the behavior of the arbitrator. As already noted, a series of referential studies demonstrate that the arbitrator's behavior does not reflect the characteristics which he/she is commonly expected to have. This primarily pertains to the standard argument that the arbitrator mechanically resorts to seeking the middle grounds between the extreme parties' offers within the traditional model of arbitration (TA). Yet, it has proven not to be true in many cases. Also, in terms of rendering arbitral decisions, there is no significant difference in the arbitrator's behavior in the TA and in the FOA. Of course, the innovative model of arbitration (FOA) has demonstrated certain advantages, which have been confirmed by its common application in some areas (such as sports).

Thus, it appears that there are no significant differences between the TA and the FOA, but this fact does not justify the view that this innovation in the ADR market is unnecessary. The higher supply of dispute resolution methods of any kind may be highly beneficial for the (potential) parties. Arbitration has proven to be a more efficient legal institute than litigation, which has been corroborated inter alia by its widespread application in resolving labour and commercial disputes. Therefore, the beneficial effects of instituting another form of arbitration (the FOA) are indisputable.

\section{REFERENCES}

1. Ashenfelter, O. (1987). Arbitrator Behavior, The American Economic Review, Vol. 77, No. 2, pp. 342-346.

2. Ashenfelter, O., Bloom, D., E. (1983). The Pitfalls in Judging Arbitrator Impartiality by Win-Loss Tallies under Final-Offer Arbitration, Labor Law Journal, Vol. 34, Issue 8, pp.534-539.

3. Ashenfelter, O., Bloom, D., E. (1984). Models of Arbitrator Behavior: Theory and Evidence, American Economic Review, Vol. 74, No. 1. pp. 111-124.

4. Benson, L., B. (2000). Arbitration, In: Bouckaert, Boudewijn and De Geest, Gerrit (ed), Encyclopedia of Law and Economics: The Economics of Crime and Litigation, Vol. V, Cheltenham, Edward Elgar.

5. Bloom, E., D. (1981). Is Arbitration Really Compatible with Bargaining?, Industrial Relations, Vol. 20, pp. 233-244.

6. Bloom, E., D. (1986). Empirical Models of Arbitrator Behavior under Conventional Arbitration, Review of Economics and Statistics, Vol. 68, pp. 578-585.

7. Burgess, L., P., Marburger, R., D. (1993). Do Negotiated and Arbitrated Salaries Differ under Final-Offer Arbitration?, Industrial and Labor Relations Review, Vol. 46, pp. 548-559.

8. Charny, D. (1990). Nonlegal Sanctions in Commercial Relationships, Harvard Law Review, Vol. 104, No. 2, December 1990, pp. 373-467.

9. Cole, R., S., Blankey, K., M. (2005). Arbitration, In: Moffitt, M., L., Bordone, R., C. (ed), The Handbook of Dispute Resolution, First edition, Jossey-Bass A Wiley Imprint, San Francisco, United States of America.

10. Crawford, P., V. (1979). On Compulsory Arbitration Schemes, Journal of Political Economy, Vol. 87, Issue 1, pp. 131-159.

11. Currie, J. (1989). Who Uses Interest Arbitration? The Case of British Columbia's Teachers, 1947-1981, Industrial and Labor Relations Review, Vol. 42, pp. 363-379.

12. Farber, S. (1981). Splitting-the-Difference in Interest Arbitration, Industrial and Labor Relations Review, Vol. 35, pp. 70-77.

13. Farber, S., H., Bazerman, H., M. (1986). The General Basis of Arbitration Behavior: An Empirical Analysis of Conventional and Final-Offer Arbitration, Econometrica, Vol. 54, pp. 819-844.

14. Farber, S., H., Bazerman, H., M. (1989). Divergent Expectations as a Cause of Disagreement in Bargaining: Evidence from a Comparison of Arbitration Schemes, Quarterly Journal of Economics, Vol. 104, Issue 1, pp. 99-120.

15. Farber, S., H., Katz, C., H. (1979). Interest Arbitration, Outcomes, and the Incentives to Bargain, Industrial and Labor Relations Review, Vol. 33, pp. 55-63.

16. Кнежевић, Г., Павић, В. (2009). Арбитража и АДР (Arbitration and ADR), Издавачки центар Правног факултета Универзитета у Београду, Београд. 
17. Lookofsky, J., Hertz, K. (2004). Transnational Litigation and Commercial Arbitration: An Analysis of American, European, and International Law, Second Edition, Juris Publishing, DJØF Publications Copenhagen.

18. Mnookin, H., R. (1998). Alternative Dispute Resolution, Harvard Law School, John M. Olin Center for Law, Economics and Business, Discussion Paper Series, Paper 232, available at: http://lsr.nellco.org/harvard_olin/232/

19. Nolan-Haley, M., J. (1991). Alternative Dispute Resolution in a Nutshell, West Publishing Company, St. Paul, Minnesota.

20. Stevens, M., C. (1966). Is Compulsory Arbitration Compatible with Bargaining?, Industrial Relations, Vol. 5, Issue 2, pp. 38-52.

21. Wooldridge, C., W. (1970). Uncle Sam, The Monopoly Man, Arlington House, New York, New Rochelle.

22. Zakon o mirnom rešavanju radnih sporova, (Act on the Peaceful Settlement of Labor Disputes), Sl. glasnik $R S^{\prime \prime}$ br. 125/2004 i 104/2009.

\section{ARBITRAŽA KONAČNIH PONUDA STRANAKA: INOVATIVNA INSTITUCIJA NA TRŽIŠTU ADR USLUGA}

U ovom radu prikazujemo novu formu arbitraže pod nazivom arbitraža konačnih ponuda stranaka, koja je nedovoljno poznata domaćoj javnosti. Radi se o arbitraži koja je počela da se koristi u američkoj praksi radi rešavanja radnih sporova u oblasti sporta i javnom sektoru. Od njenog nastanka ona je privukla pažnju teoretičara i istraživača koji se se bavili ispitivanjem njene efikasnosti u odnosu na tradicionalnu formu arbitraže. S tim u vezi, u ovom radu, prvo, prikazujemo dosadašnja teorijska $i$ empirijska saznanja o prednostima tradicionalne arbitraže $u$ odnosu na parnicu, a potom o komparativnoj prednosti arbitraže konačnih ponuda stranaka u odnosu na tradicionalnu arbitražu, pre svega, u pogledu efikasnosti. Posebno interesantno pitanje jeste koji od ova dva modela arbitraže (tradicionalni ili inovativni) pruža snažnije podsticaje stranama u sporu u pravcu pregovaranja $i$ sklapanja poravnanja.

Ključne reči: tradicionalna arbitraža, arbitraža konačnih ponuda stranaka, efikasnost, pregovaranje, poravnanje. 